\title{
LIETUVOS ISTORINIŲ PARKŲ RAIDOS ANALIZĖ IR KAI KURIE JŲ ATKÜRIMO PROBLEMOS ASPEKTAI
}

\author{
Konstantinas Jakovlevas-Mateckis \\ Miestu statybos katedra, Vilniaus Gedimino technikos universitetas, \\ Saulètekio al. 11, 10223 Vilnius, Lietuva \\ El.paštaskm@vgtu.lt \\ Itteikta 20110420
}

Santrauka. Istorinių parkų apsaugos, tvarkymo ir atkūrimo procesui įtaką daro visas veiksnių kompleksas. Todèl trumpai analizuojama Lietuvos istorinių sodų ir parkų meno stilių raida ir jų būdingų bruožų sankaupa, šalies istorinių parkų apsaugos, tvarkymo ir atkūrimo teisinès bazès būklè ir istorinių parkų atkūrimo praktikos teigiami bei neigiami aspektai. Pateikiami pasiūlymai šalies istorinių parkų atkūrimui pagerinti.

Reikšminiai žodžiai: istoriniai parkai, valstybinės reikšmės parkai, parkų meno stilius, parkų atkūrimas, parkų atkūrimo teisinė bazė.

\section{Ivadas}

Istoriškai susiformavusiame kultūriniame kraštovaizdyje svarbią vietą užima istoriniai želdynai (parkai, sodai, skverai ir pan.), kurie turètų būti saugomi ir tvarkomi kaip vertingas kraštovaizdžio architektūros paveldas. Tačiau dažniausiai šie tikslai yra neįvertina$\mathrm{mi}$, ir istoriniai želdynai, netinkamai perprojektavus, keičiami, žalojami arba naikinami. Ir tai dažnai atsitinka ne tik rajonuose, bet ir didžiausių šalies miestų senamiesčiuose ir pan. Pavyzdžiui, Vilniuje istorinio Bazilijonu vienuolyno komplekse, buvusio istorinio vienuolyno sode, pastatytas Tarptautinès verslo mokyklos auditorijų korpusas bei automobilių stovejjimo aikštelès. Dažnai pasitaiko atvejų, kai istoriniuose kiemuose irrengiamos perdangos ir jie paverčiami kompleksų patalpomis (Pilies g. 10 kiemo vietoje įrengtas viešbučio „Artrium“ holas bei restoranas ir daugelis kt.). Dažnai kuriant ar rekonstruojant skverus ignoruojama jų buvusi istorinè planinè erdvinè struktūra. Taip atsitiko rekonstruojant Moniuškos skverą, kurio suplanavimas ne atkuria, o pažeidžia Šv. Kotrynos bažnyčios ir vienuolyno ansamblio vientisumą (Pasaulio ... 2009). Labai daug trūkumų yra istorinių Lietuvos parkų atkūrimo procese, tai akivaizdžiai at- sispindi Vilniaus Sereikiškių parko atkūrimo techniniame projekte (Jakovlevas-Mateckis 2008).

LR Valstybine kultūros paveldo komisija (VKPK), vadovaujama prof. J. Glemžos, 2005 m. konstatavo, kad „dèl priežiūros ir reikiamos apsaugos stokos daugelis istorinių želdynų prarado savo vertingąsias savybes, sumenko. Nors dvarų parkų yra daugiau kaip 300, tačiau dauguma jų - blogos būklès" (LR VKPK spr. 2005). Pastaraisiais metais a ktualizuojant istorinių želdynų apsaugos ir tvarkymo problemą, ívyko poslinkių. 2010 m. LR VKPK, vadovaujama G. Drèmaitès, savo sprendime pažymèjo, kad „Lietuvoje 1990-2010 metais neatkurtas nè vienas istorinis želdynas, tačiau jau esama restauruojamų, atkuriant sunaikintas parkų dalis (Užutrakis, Verkiai, Palanga, Rietavas, Kuršènai, Taujènai, Šešuolèliai, Aštrioji Kirsna, Kurtuvènai, Frenkelio rūmų istorinis želdynas)" (LR VKPK spr. 2010). Tačiau tai tik lašas jūroje, nes didžioji dalis mūsų šalies istorinių parkų nyksta, praranda savo vertę, autentiškumą ir vientisumą.

Esama būklè verčia šalies visuomenę ir kraštovaizdžio architektūros specialistus, mokslininkus suklusti, imti analizuoti priežastis, kodèl taip yra ir ką reikia 
daryti, kad istoriniai želdynai (parkai, sodai, skverai) būtų geriau saugomi, teisingiau atkuriami ir tvarkomi. Todèl autorius šiame darbe bando pateikti trumpą Lietuvos istorinių parkų raidos analizę ir atskleisti sankaupą jų stiliui būdingų bruožų, kurie atkūrimo procese turètų būti ypač kruopščiai įvertinti. Darbe apžvelgta istorinių parku apsaugos, tvarkymo ir atkūrimo teisinès bazès būklè ir išnagrinèta keliu parkų atkūrimo praktika.

\section{Istorinio želdyno samprata ir sąvokos}

Kraštovaizdžio architektūros profesinès ir mokslinès veiklos plètra skatina tobulinti vartojamų terminų bei jų sampratų ir sąvokų apibréžimus.

$1981 \mathrm{~m}$. kraštovaizdžio architektūros istorijoje ICOMOS èmé vartoti terminą - ,istoriniai želdynai“, kuris buvo pateiktas patvirtintoje istorinių želdynų chartijoje, dabar dažniausiai vadinamoje „Florencijos chartija“. Pagal ICOMOS istorinių želdynų chartiją „Istorinis želdynas - tai architektūros ir parkų meno kompozicija, kuri domina visuomenę istorijos ir meno požiūriu; tai architektūros kompozicija, kurios didžiąją dalị sudaro augalija" (Florencijos... 1981). Nuo to laiko istoriniai želdynai tapo nekilnojamojo kultūros paveldo objektais, kurie sudaro atskirą kultūros paveldo grupę. Kultūros paveldas - tai karta iš kartos paveldimos, perimamos, sukurtos ir perduodamos kultūros vertybès, svarbios etniniu, istoriniu, estetiniu ar moksliniu požiūriais.

Istoriniais želdynais laikomi miestų, miestelių, dvarų parkai, sodai, skverai, vienuolynų ir pilių sodai ir pan., pasižymintys savo kultūros vertybèmis. Pagal 2004 m. LR nekilnojamojo kultūros paveldo ịstatymą „Istoriniu želdynu vadinamas bet kokio dydžio želdynas, turintis išliekamąją stilistinę, meninę vertę arba priklausantis svarbiems urbanistinès raidos etapams, susijęs su visuomenès, kultūros ar valstybès ịvykiais arba asmenybėmis“. Todèl valstybès ir visuomenès tikslas yra ne tik saugoti, tvarkyti, bet ir atkurti istorinius želdynus.

Istorinio želdyno atkūrimas - tai kompleksinis želdyno tvarkymas, kai grąžinama autentiška želdyno planinè erdvinè struktūra ir kompozicija, jo stiliaus pagrindinių bruožų visuma. Todèl labai svarbu teisingai suvokti stiliaus sąvoką. Labai gaila, kad dar ir šiandien mūsų šalies profesionalioje ir didaktinejje kraštovaizdžio architektūros literatūroje vartojami pasenę ir neteisingi Lietuvos istorinių parku meno stilius nusakantys terminai, tokie kaip reguliarusis, peizažinis ir mišrusis stiliai. Tokių stilių dabartineje kraštovaizdžio architektūros teorijoje ir istorijoje nèra, nes negalima apibrèžti ir ịvardinti istorinio parko stilių pagal vieną jo požymi - planinę struktūrą. Kaip teisingai teigia prof. Nijolè Lukšionytè, ,,stilius - tai charakteringu bruožu sankaupa, būdinga atskiriems meno raidos laikotarpiams, pasireiškianti tam tikroje kultūrinejje ter-

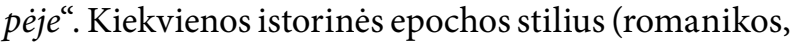
gotikos, renesanso, baroko, klasicizmo, istorizmo, moderno, modernizmo) susiklosto veikiamas socialinių, kultūrinių, religinių veiksnių bei paties meno raidos dėsningumų. Tarp stilių nèra griežtos chronologinès užgimimo ir pabaigos ribos. Esamo stiliaus terpeje visuomet bręsta būsimo stiliaus daigai arba prielaidos (Lukšionytè 2008). Kraštovaizdžio architektūroje stilius suprantamas kaip vienove pasižyminti planinių erdvinių, kompozicinių, estetinių principų visuma. Bègant amžiams architektūros ir kraštovaizdžio architektūros stiliai vystèsi drauge. Tai ypač ryškiai atsispindi istorinių dvarų kompleksuose.

Kaip nurodo prof. J. Adomonis, architektūros ir kraštovaizdžio architektūros meninejje aplinkoje formavosi ir taikomoji dekoratyvinè daile, kuri kartu su architektūra bei kraštovaizdžio architektūra veikè materialinị ir dvasinị žmoniu gyvenimą (Adomonis 1994).

Visais istorinių stilių laikotarpiais sodų ir parkų mene svarbų vaidmení atliko ir mažoji architektūra. Mažoji architektūra - tai mažieji statiniai, dekoratyviniai vandens ir pramogu irenginiai, lauko baldai, laiptai ir atitvarai, vizualines informacijos, apšvietimo ìrenginiai ir pan. Istoriniuose želdynuose mažoji architektūra išryškina stilistinę ir meninę jų vertę (Jakovlevas-Mateckis 2008).

Miestų planavimo srityje ir kraštovaizdžio architektūroje dažnai vartojama ir speciali sąvoka genius loci, skirta vietos dvasiai ịvardinti. Žmoguje glūdi poreikis ,gyventi poetiškai“, identifikuoti save su vieta, ją priimti ir kūrybiškai dalyvauti jos istorijoje (Markejevaitė 2002). Šis poreikis - ,gyventi poetiškai“ - ịvairiais istoriniais laikotarpiais pasireikšdavo skirtingai ir, reikia pripažinti, atkuriant istorinius želdynus yra dažnai neịvertinamas. Istorinių parkų aplinkoje turètų atsispindèti ir jaustis jų laikotarpio dvasia - genius loci, ji parke turi būti ịprasminta.

Istorinių želdynų tipologijoje svarbią vietą užimantys istoriniai parkai ir sodai pagal vertingumą ir reikšmingumą dažnai skirstomi ị kelis lygmenis: valstybinès, regionines ir vietines reikšmès parkus. Pagal LR želdynų i̇statymą, „Valstybinès reikšmès parkas parkas, turintis ypatingą istorinę, architektūrinę, kultūrinę, mokslinę, estetinę ir dendrologinę vertę" (Želdynų... 2007).

Atkuriant ir atnaujinant istorinius parkus ir sodus, rengiant jų projektinę dokumentaciją dažnai susiduriama su terminais ,, atkūrimas“, „,rekonstrukcija“, ,renovacija“ ir pan., kurie gana dažnai neteisingai vartojami ar neteisingai interpretuojamos jų sąvokos. Panagrinèjus šių terminų apibrèžimus Tarptautinių 
žodžių žodyne (2004), tenka konstatuoti, kad tarp terminų „restauracija“ ir "rekonstrukcija“ nèra aiškios atskirties, apibrèžimų sąvokos šiuose terminuose kai kur kartojasi ir pan. Toks terminų neapibrèžtumas sukelia painiavą projektiniuose, moksliniuose darbuose, teisiniuose aktuose ir pan. Vartojamų terminu teisingumas priklauso nuo išsikelto tikslo ir uždavinių, kurie numatomi atlikti norint pasiekti šị tikslą. Todèl trumpai bus paaiškintos šiu terminu sampratos ir sąvokos. Pagal Lietuvos Respublikos želdynų i̇statymą „Istorinio želdyno atkūrimas - kompleksinis želdyno tvarkymas, kai grąžinama autentiška želdyno struktūra ir kompozicija“. İstatyme pateikta apibendrinta „,istorinio želdyno atkūrimo“ sąvoka. Atkuriant istorinius želdynus, o ypač istorinius parkus, jų atkūrimo proceso tikslai ir pagrindiniai uždaviniai gali būti, kad ir nežymiai, tačiau skirtingi. Tačiau visais atvejais turi būti atkurta autentiška planinè erdvinè istorinio parko struktūra, kompozicija ir jų būdingų meninių bruožų visuma. Todèl istorinio parko atkūrimo procesas galètu būti atliekamas trimis būdais: atstatant, nežymiai pertvarkant ir atnaujinant. Šio straipsnio autorius siūlytų vartoti labiau diferencijuotus istorinių parkų atkūrimo terminus: ,atstatymas“, „nežymus pertvarkymas“, ,atnaujinimas".

- Istorinio parko ar sodo atstatymas - tai sunaikinto, neišlikusio parko pirmykštès autentiškos būklès, jo planinès erdvinès struktūros ir kompozicijos atkūrimas, ji atstatant pagal turima archyvinę medžiagg ir analogus. Pavyzdžiui, Vilniaus Žemutinès pilies valdovų rūmų XVI a. renesansinį sodą galima ir net reikia atstatyti pagal turimą archyvinę medžiagą ir analogus.

- Istorinio parko atstatymas ir nežymus pertvarkymas - tai parko ar jo dalies autentiškos planines erdvinès struktūros ir kompozicijos atkūrimas pagal išlikusius parko fragmentus arba dokumentus ir jo tolesnis panaudojimas pagal nauja paskirti, nepažeidžiant būdingu stiliaus bruožu visumos. Pavyzdžiui, Vilniuje Sapiegų rezidencijos barokini parką puikiausiai galima atkurti pagal šiame parke išlikusius barokinio stiliaus požymius, ano laikotarpio parkų analogus ir nežymiai pertvarkius panaudoti muziejinei bei reprezentacinei miesto veiklai.

- Istorinio parko atnaujinimas - tai parko atnaujinimas išsaugant jo autentiškuma ir charakteringu stiliaus bruožu visuma. Šis terminas vartotinas, kai atliekami tik parko atnaujinimo, tvarkymo ir pan. darbai.

Ivertinus pateiktų terminų ypatumus, istorinių parkų mokslineje ir projektineje tvarkymo bei apsaugos veikloje, atsižvelgiant ị išsikeltą tikslą, reikia vartoti ir atitinkamą terminą. Būtų tikslinga dar šiais klausimais padiskutuoti ir siekti, kad šie terminai būtų pateikti ir su želdynais susijusiuose teisès aktuose, taip jie būtų ịteisinti, ir būtų išvengta neteisingo jų vartojimo bei interpretavimo.

\section{Trumpa Lietuvos istorinių sodų, parkų meno stilių raida ir būdingụ jų bruožų analizè}

Lietuvos kultūros paveldo lobyne ypač svarbią vietą užima ir neikkainojamą vertę šiandieniniame globalizacijos amžiuje turi istoriniai parkai ir sodai.

Europoje ir Lietuvoje prasidejęs istorinių parkų bei sodų atkūrimo procesas reikalauja išsaugoti ar grąžinti jų autentiškumą, stilistinių ir meninių bruožų sankaupą, būdingą atskiriems meno raidos laikotarpiams. Todèl toliau bus trumpai apžvelgta įvairių laikotarpių Lietuvos istorinių parkų raida.

Sodų, parkų menas Lietuvoje suklestëjo, kai ị Lenkijos ir Lietuvos Didžiosios Kunigaikštystès (LDK) sostą atejo Žygimanto Senojo sūnus Žygimantas Augustas, kuris 1557 m. pradejo milžinišką žemès reformą. Valakų reformos tikslas buvo padidinti žemès ūkio našumą ir kartu gauti daugiau ịplaukų i iždą. Šalyje kūrèsi valakiniai ūkiai, kaimai, augo dvarai, palivarkai, miesteliai. Prie dvarų, palivarkų buvo statomi ne tik rūmai, bet ir sodinami parkai, sodai. Miestų priemiesčiuose didikai statèsi rezidencijas su parkais ir pan. Tai buvo ekonominio sustiprejimo ir Renesanso idejų plitimo Lietuvoje laikotarpis, vyko perejjimas nuo dominavusios feodalinès ir religinès mąstysenos prie humanistinès pasauležiūros, visuomenès domèjimosi praeitimi, antikos laikų palikimu, jo architektūra.

Renesanso stiliaus sodų kompozicijoje atsispindèjo Renesansui būdinga žmogaus viršenybès gamtoje ideja. Sodo planas buvo geometrinis, simetriškas ar asimetrinis, turèjo dažniausiai vieną kompozicinę aši, kuri rèmèsi į kompozicijos dominantę. Lygiagrečiai su pagrindiniu taku ir statmenai jam eidavo antraeiliai takai, kurie sudalydavo teritoriją dažniausiai i kvarterius (kvadratus) ar stačiakampius. Šie kvarteriai buvo puošiami karpytų medžių ir krūmų kompozicijomis. Renesanso sodai buvo nedideli, tačiau gausiai buvo puošiami fontanais, skulptūromis ir pan. (1 pav.).

Puikiu renesanso stiliaus sodu garsèjo Vilniuje Žemutinès pilies Valdovų rūmai, renesansiniai sodai puošè Vyskupų, didikų Radvilų ir Goštautų rūmus, vienuolynų kiemus ir pan.

Dabartiniu metu jau yra baigiami atkurti Vilniuje Žemutinès pilies Valdovu rümai todèl, šio straipsnio autoriaus manymu, bütina imtis žygiu atkurti ir šalia rūmų XVI a. buvusį nepaprasto grožio renesansi$n i ̣$ sodą. Jis (žiūrint iš dabartinès Pilies g.) būtų prie 


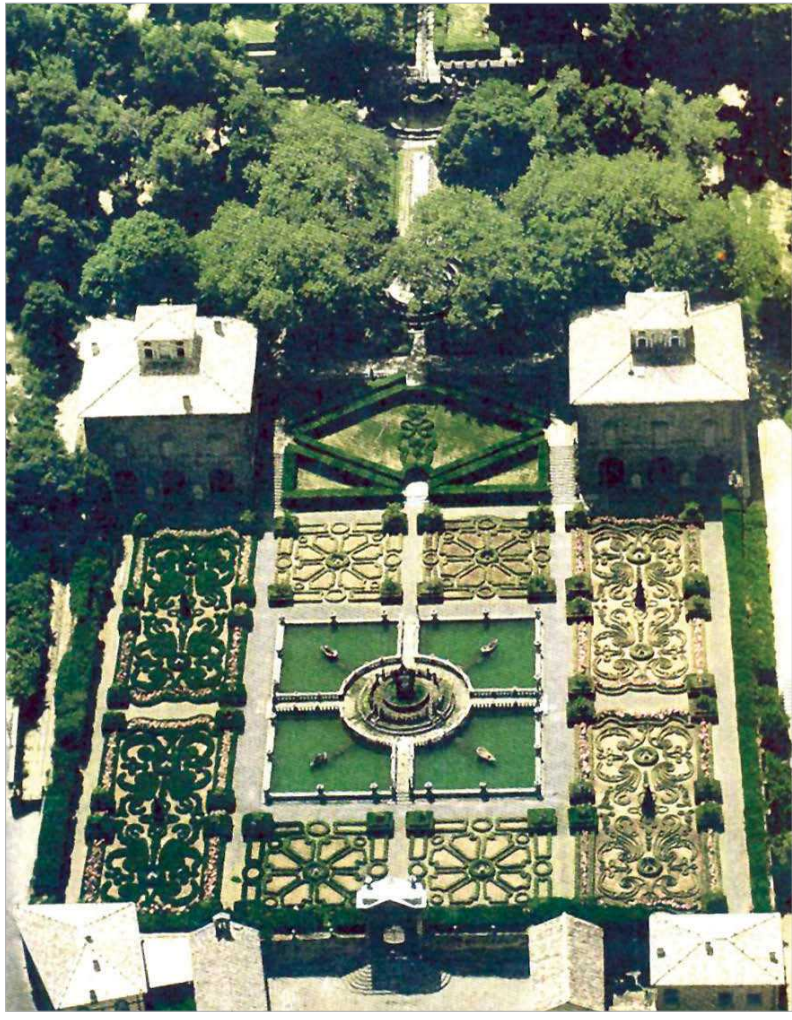

pagrindinio įejjimo ị rūmus ir tęstųsi ị dešinę pusę, užimtų teritoriją, esančią prieš Valdovų rūmus, ir dalị dabartinio želdyno, sudarytų puikų foną Valdovų rūmams ir Gedimino paminklui. Renesansiniame sode šio straipsnio autorius siūlo ịkomponuoti Lietuvos Didžiųjų kunigaikščių biustus, taip būtų îprasmintas jų istorinis reikšmingumas. Šis sodas atliktų didžiuli auklejjamąjị ir didaktinị vaidmenị.

XVII a. didikų rūmų sodai ir parkai, ypač Italijoje, Prancūzijoje, tapo labai įmantrūs ir puošnūs. Gime naujas baroko stilius. Barokinio pasaulio kūrybos tikslas - pamègdžioti gamtos sudètingumą, ją atkuriant viso menų komplekso priemonemis ir visomis formomis. Tuo metu ypač garsèjo ir Vilniuje, Antakalnio priemiestyje, pastatyti Sluškų ir Sapiegų rūmai su puikiais barokiniais parkais. Barokiniai parkai buvo geometrinio suplanavimo, pabrèžtos ašinės kompozicijos, kurios branduolį sudarè rūmai ir priešais ịrengta reprezentacinè aikštė su puošniais parteriais. Už rūmų vidineje puseje buvo įrengiama intymioji parko dalis, sudalinta ị geometrinès formos sektorius (bosketus), apsuptus reguliariai karpomų medžių gyvasienėmis ir krūmų gyvatvorèmis, kurių viduje kartais buvo išdèstyti žalieji kabinetai, labirintai ir pan.

Parkuose dominavo tiesios spindulinès ar žvaigždinès alejjos, prie jų buvo statomi paviljonai, žalieji teatrai, įrengiami dideli įmantrių formų dekoratyviniai baseinai, kanalai, fontanai su skulptūromis, parteriai padalyti geometriniais takeliais, iškilmingi laiptai, kar-
1 pav. Lante vilos (Villa Lante) Bagnaia miestelyje netoli Romos (Italija) renesansinis sodas (aut. Giacomo Borozzi Vignola; ikurtas 1566-1580 m.). Sodo parteris, užimantis $4000 \mathrm{~m}^{2}$, vadinamas Quadrato, padalintas i 16 mažesnių, vienodo dydžio kvadratiniu kvarterių. Sode medžiai ir krūmai meniškai karpomi, iš ju formuojamos gyvatvorès, žaliosios skulptūros ir ornamentai. Tipiško renesansinio sodo vaizdas nepakito iki šių dienų. Panašaus pobūdžio renesanso stiliaus sodas turètų būti įrengtas ir Vilniuje prie Valdovų rūmų

Fig. 1. The renaissance-style garden of Villa Lante in the town of Bagnaia, close to Rome, Italy (established in 1566-1580, by Giacomo Borozzi Vignola). The parterre of the garden - which occupies $4000 \mathrm{~m}^{2}$ and is referred to as Quadrato - is divided into 16 smaller quarters of equal size. Trees and bushes of the garden are artistically trimmed to form hedges, green sculptures and ornaments. The typical view of the renaissance-style garden remains the same to this day. A similar type of renaissance-style garden should be designed next to the Palace of the Grand Dukes in Vilnius

pomi medžiai ir krūmai, ịvairių konfigūracijų žaliosios sienutès, taip pat įmantrių piešinių parteriai, gèlynai ir vejos. Dažnai parkas jungdavosi su mišku, kuriame būdavo ịrengtas žvèrynas.

Puikūs baroko stiliaus parkai buvo kuriami ir kitose LDK teritorijose, tai didikų Radvilų rūmai su parku Nesvyžiuje, Sapiegų rūmai su parku Ružanuose, Bresto srityje ir kt.

Tačiau tenka apgailestauti, kad dabartineje Lietuvos teritorijoje neišliko buvusių puikių baroko stiliaus sodų ir parkų, kurių didžioji dalis buvo perprojektuoti, o likusieji - sunyko. Todel jau šiandien reikia imtis žygiu atkurti bent kelis baroko stiliaus parkus. Pirmuoju atkuriamuoju barokinio stiliaus parku turèty tapti Sapiegy rezidencijos parkas Vilniuje. Šiame parke turètų būti iprasmintas Lietuvos Didžiosios Kunigaikštystės didikų Sapiegų giminès istorinis reikšmingumas.

XVIII a. naujos švietimo ir kultūros idejos Europoje, ypač Didžiojoje Britanijoje, atvèrè vartus naujam architektūros stiliui - klasicizmui. Klasicizmo šalininkai smerkè perdètą barokinių formų didingumą ir prabangą. Formalų baroko stiliaus parkų ir sodų geometrini suplanavimą èmè keisti kraštovaizdinis (vadintas peizažiniu). Buvo siekiama prieš rūmus sukurti reprezentacini geometrinių formų parterą, o už rūmų atkurti ir atverti natūralaus kraštovaizdžio grožị ir formas. Parko planas kontrastavo su pastatų architektūra, jame ịsivyravo plastiškų, vingiuotų takų ir takelių tinklas, kuris buvo paremtas perspektyvų ir 
vizualių ryšių sukūrimu ir pagrindinès kompozicinès ašies išryškinimu. Parkų erdvėse buvo kuriamas šviesos ir šešèlių žaismas. Parkų teritorijoje saikingai buvo naudojami antiką menantys, mažosios architektūros objektai ir skulptūros, jų vieta pagrịsta racionalumu ir kompoziciniu užbaigtumu. Šio stiliaus parkai dažnai buvo vadinami angliškaisiais parkais.

Lietuvoje prie kraštovaizdiniu klasicizmo parkų galima priskirti Pakruojo, Taujènų, Joniškèlio, Raguvèlès, Verkių ir daugelį kitų dvarų parkų. LDK teritorija (dab. Baltarusija) taip pat garsejo klasicizmo stiliaus parkais, tai didikų Tyzenhauzų, Oginskių, Pastovio, Visoko parkai, Radvilų giminès rezidencija su parku Radzivilimontuose ir kt. (Mocevičius 2010) (2 pav., a, b).

XIX a. viduryje Lietuvoje ima įsigalèti romantizmo stiliaus parkai, kuriuose buvo siekiama perteikti natūralaus kraštovaizdžio groži, išgauti tapybiškiausią gamtos (vandens, reljefo, želdinių) kompoziciją, papuoštą ne tik antikinę, bet ir viduramžiu architektūrą ir skulp-
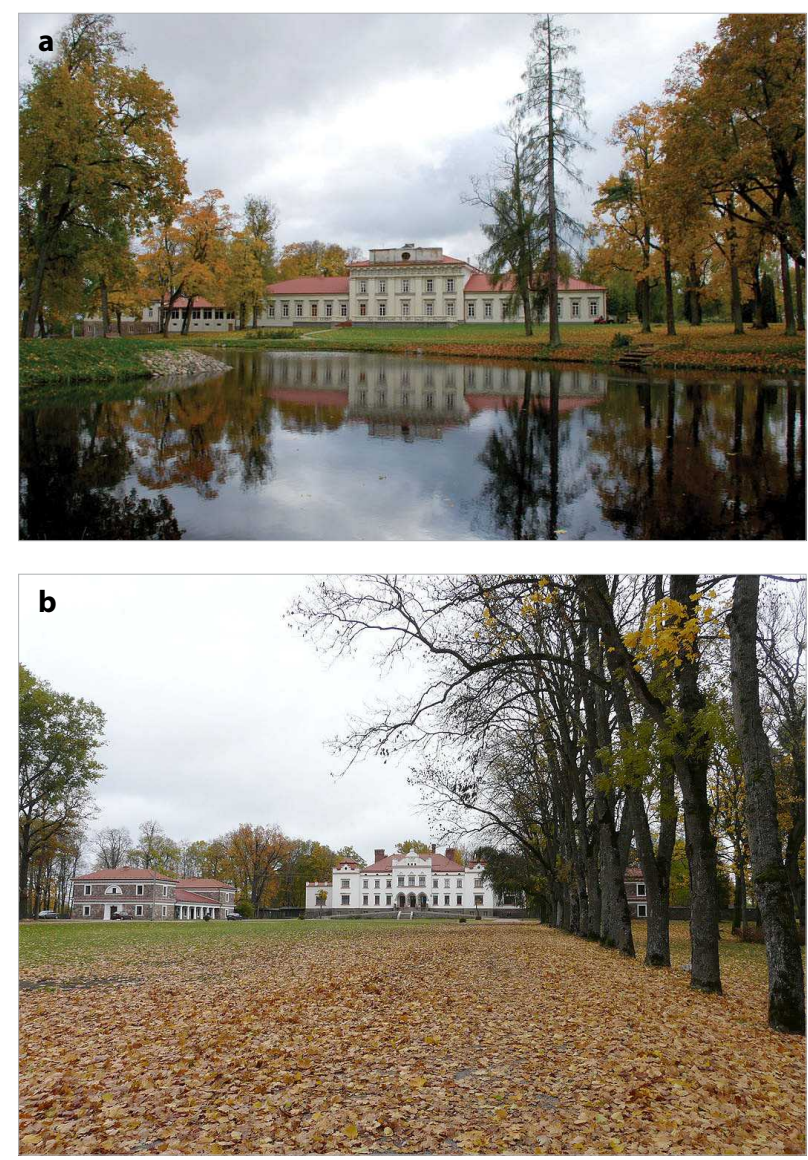

tūrą menančiais elementais (portikais, kolonadomis, pilių bokštų bei sienų griuvèsiais ir pan.) romantiškam nusiteikimui sustiprinti. Lietuvoje toks būdingas romantizmo stiliaus parkas buvo suformuotas Kairenu dvare prie Vilniaus (dabar čia Vilniaus universiteto botanikos sodas), Pagryžuvio dvare (Kelmès raj.), Baisogalos dvare ir kitur.

XIX a. antrojoje pusèje Lietuvoje parkai pradèti kurti istorizmo, dažnai vadinamo eklektikos, stiliumi. Juose buvo tęsiamos parkų romantizmo stiliaus tradicijos, tačiau perdem jau buvo siekiama imituoti praeities ar net suplakti kelių praeities epochų sodų ir parkų meno stilių bruožus. Garsiausius istorizmo stiliaus parkus Lietuvoje sukūrè prancūzų kraštovaizdžio architektas E. F. Andre Palangoje, Užutrakyje, Trakų Vokejje ir Lentvaryje. Puikiai šio stiliaus požymiai atsispindi ir M. Oginskio Plungès bei Slonimo (dab. Baltarusija) dvarų parkuose (2 pav., c).

XIX a. pabaigoje Lietuvą pasiekè moderno stilius (Lenkijoje vadinamas secesija, Vokietijoje - jugendstiliumi ir pan.), kurio svarbiausias principas - kurti naują stilių, atsiriboti nuo istorinių formų bei schemų. Ši stilių žinoma Lietuvos architektūrologè profesorè N. Lukšionytė apibūdina kaip antiistorizmo judejimą. Šis stilius atsispindi ir puikiai išsilaikiusiame Vilniaus Sereikiškių parke (aut. dail. A. Strauss, 1886-1888 m.), kuris buvo pirmasis viešasis parkas Lietuvoje. Parkas pasižymi šiam stiliui būdingu asimetriniu suplanavimu ir parko erdvių elegancija, jame numatytas iškilmingas iejjimas ị parką, kurị sudare būdinga šiam stiliui trumputė „dengta“ susiveriančių liepų alèja (covered alley, alley couverte, alleja kryta), už kurios, einant atviru

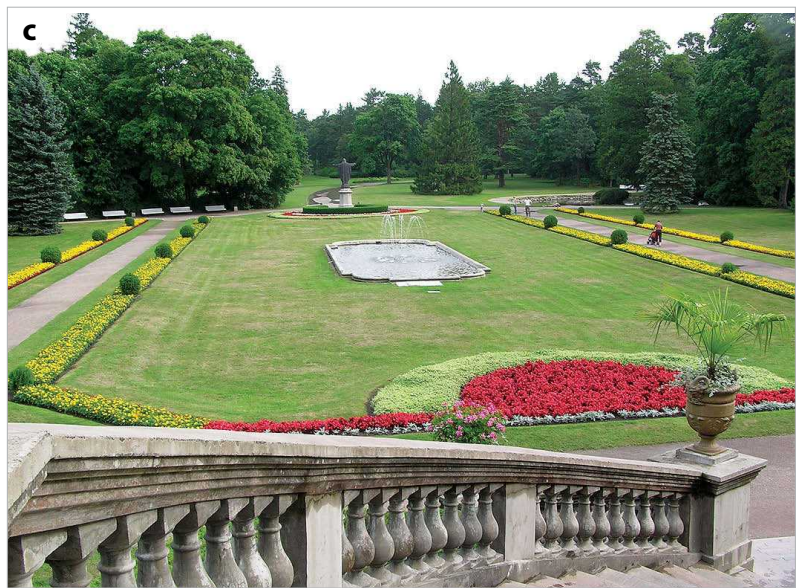

2 pav. Lietuvos istorinių parkų vaizdai (L. Januškevičiaus nuotr.): a - Taujènų dvaro klasicistinio stiliaus parkas; b - Rokiškio dvaro ansamblio barokinio klasicizmo stiliaus parko fragmentas; c - Palangos istorizmo stiliaus parko reprezentacinio parterio vaizdas (archit. E. F. Andre, 1897-1900 m.)

Fig. 2. Images of historic parks of Lithuania (photos by L. Januškevičius): a - the classicistic park of Taujenai Manor; $b$ - a fragment of the baroque-classicistic park of Rokiškis Manor ensemble; c - image of the representative parterre of the historicism-style park in Palanga (architect E. F. Andre, 1897-1900) 
taku, atsiveria saulès apšviestos i̇spūdingos parko erdvès, per kurias nuvilnija lenkti kaligrafiniai takai ir takeliai, primenantys plastiškas augalijos formas, vejoje matyti gražių ovalinių formų tvenkiniai su tilteliu ir pan. İkurtame parke puikavosi moderno stiliaus parodų paviljonas ir kiti lieto metalo konstrukcijų mažosios architektūros objektai. Parkas ir paviljonas, pasižymintys moderno stiliui būdingais bruožais, sudarè labai ispūdingą ir harmoningą visumą. $2010 \mathrm{~m}$. pradètas rekonstruoti parkas buvo nemokšiškai sužalotas (3 pav.).

$\mathrm{XX}$ a. trečiajame-ketvirtajame dešimtmetyje Lietuvos architektūros ir kraštovaizdžio architektūros objektų sprendiniuose ima reikštis modernizmo stilius. Būdingas šio stiliaus pavyzdys - Karo muziejaus sodelis Kaune, Alytaus miesto sodas, Rietavo miesto aikšte ir kt. Romantizmo, istorizmo, moderno stilių atstovai siekè sodų, parkų sprendinių harmonijos su užstatymo architektūra, o modernizmo stiliaus kūrèjai susiejo pastatus su gamtine aplinka kontrasto principu. Šiam stiliui būdingas geometrinis, dažniausiai stačiakampis takų ir aikštelių suplanavimas ir simetrinè kompozicija. Didesnių parkų, sodų teritorijose toliau nuo pastatu buvo daromi ir plastiškų formų takai. Modernizmo stiliaus įvairios kūrybinès šakos reiškiasi ir šiuolaikineje kraštovaizdžio architektūroje ${ }^{1}$.

Modernizmo stiliaus kraštovaizdžio architektūros raidą 1940 m. nutraukè Tarybų Sąjunga, kuri okupavo Lietuvą, ir pražūtingieji Antrojo pasaulinio karo 1941-1945 m. padariniai. Po karo, pasikeitus politinei ir ekonominei Lietuvos santvarkai, keitèsi ir miestų

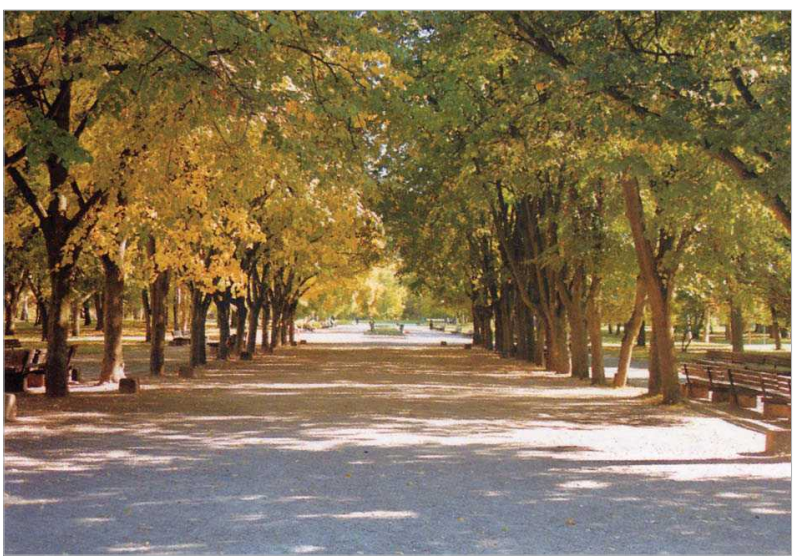

3 pav. Vilniaus Sereikiškių moderno stiliaus parko centrinès alejos vaizdo fragmentas (aut. dail. A. Strauss, 1886-1888 m.)

Fig. 3. A fragment of the image of the central avenue of a modern-style Sereikiškių park in Vilnius (author artist A. Staruss, 1886-1888)

\footnotetext{
${ }^{1}$ Smulkiau apie Lietuvos sodų, parkų meną žiūr. K. JakovlevasMateckis. 2009. Miesto kraštovaizdžio architektūra. I tomas. Miesto kraštovaizdžio architektūros raida ir teorijos pagrindai. Vilnius: Technika.
}

planavimo, pastatų architektūros bei kraštovaizdžio architektūros politika. Tačiau tarybinio laikotarpio kraštovaizdžio architektūros pasiekimai bei praradimai yra beveik nepradèti nagrinèti ir vertinti.

Autoriaus atlikta trumpa Lietuvos istorinių sodų, parkų meno raidos analizė liudija, kad šalyje turime puikių visų kraštovaizdžio architektūros stilių parkų, išsaugojusių vertingųjų savybiu visumą. Šiandien šie parkai yra neikainojama šalies kultūros paveldo vertybè. Todèl pagrindinis visuomenes ir valstybes tikslas yra išsaugoti šį kultūros palikima, jo istorinį ir kultūrinị reikšminguma, o atkuriant išlaikyti jų ir konkretaus istorinio periodo stiliaus tapatuma, autentiškuma, budingu bruožu sankaupa ir laikotarpio dvasią.

Šiam tikslui igyvendinti reikia per kelerius metus atlikti kompleksinius mokslinius istoriniu parku tyrimus, parengti ju apsaugos ir tvarkymo, integravimo $i$ visuomenes gyvenima galimybiu studijas. Šiems darbams atlikti LR kultūros ir aplinkos ministerijos turètu patvirtinti programa ir jai skirti reikiama finansavima. Paskui bütų galima atlikti projektavimo ir igyvendinimo darbus.

\section{Lietuvos istorinių sodų, parkų apsaugos, tvarkymo ir atkūrimo teisinès bazès būklè}

Vienas iš svarbiausių valstybinès kraštovaizdžio politikos strategijos uždavinių yra sukurti šiuolaikišką, Lietuvos nacionalinius interesus ir Europos Sąjungos reikalavimus atitinkančią kultūrinio kraštovaizdžio apsaugos, tvarkymo ir naudojimo sistemą, kuri padètų išsaugoti šalies nekilnojamąji kultūros paveldą istorinius želdynus ir svarbiausius jų objektus - sodus ir parkus.

Lietuvoje iki šių dienų išliko apie 900 dvarų bei dvarviečių, identifikuota apie 300 dvarų parkų, tačiau šių kultūros vertybių vaizdas, apsauga ir priežiūra, kaip teigia žinomas šalies parkotyrininkas doc. dr. L. Januškevičius, daugeliu atvejų yra nepatenkinami. 1999-2010 m. atliktų 177 dvarų parkų būklès tyrimų rezultatai išraiškingai parodè, kad labai geros būklès buvo tik 13 parkų; geros - 26; patenkinamos - 61 ir blogos - 77 parkai. Blogųų ar vadinamujju apleistų parku grupei reikètų priskirti Astravo, Apytalaukio, Kèdainių, Terespolio, Šaukėnų, Salantų, Vèžaičių, Noriūnų, Arnionių, Jiezno, Beinošavos, Jašiūnų, Paežerių (Šiaulių raj.), Biržuvėnų, Baltosios Vokès, Maišiagalos ir kt. (Januškevičius 2010). Gal nežymiai geresnès būklès yra miestų parkai.

Istoriniuose Lietuvos parkuose taip pat nepatenkinamai vykdomi atkūrimo darbai. LR Valstybinès kultūros paveldo komisijos $2010 \mathrm{~m}$. lapkričio $26 \mathrm{~d}$. sprendime „Dèl Lietuvos istoriniu parkų ir sodu apsaugos“ nurodyta, kad „Lietuvoje 1990-2010 metais neatkurtas 
nei vienas istorinis želdynas, tačiau esama tik dabartiniu metu restauruojamų parkų atkuriant sunaikintas parkų dalis. Ši veikla vykdoma Užutrakio, Palangos, Verkių, Kuršènų, Taujènų, Šešuolèlių, Aštriosios Kirsnos, Rietavo ir Kurtuvenų parkuose“.

Šiandien, kaip tvirtina L. Januškevičius, ypač visuomenę jaudina privatizuotų Lietuvos dvarų sodybų ir senụjų dvarų parkų likimas. Šiuo metu privačiose rankose atsidūré apie 30 proc. senuju šalies parku. Privatizuojant buvo galvojama, kad tai reali galimybè išsaugoti šiuos svarbius kultūros paveldo objektus. Tačiau nereti atvejai, kada privatizuotas kultūros paveldo objektas visiškai apleidžiamas, netgi nuniokojamas, o kaltų lyg ir nelieka. Konkretus tokio aplaidumo pavyzdys - privatizuota Belvederio dvaro sodyba ir parkas.

Pasitaiko atvejų, kai naujasis parko savininkas neblogai sutvarko tik reprezentacinę dvaro rūmų parko dali, o už rūmų esantis parkas paliekamas likimo valiai. Taip atsitiko Vidiškių dvare (Ignalinos raj.) (Januškevičius 2010).

Susidariusi padetis rodo, kad valstybè, privatizuodama kultūros paveldo objektus, turi ir po šio proceso nuolat kontroliuoti, kaip šie objektai saugomi, tvarkomi ir naudojami. Esant pažeidimams - bausti savininkus ir priversti apmokèti padarytus nuostolius ar imtis konkrečių žygių ir perimti iš savininkų šiuos objektus įstatymų numatyta tvarka visuomenès reikmèms, nustatyti jų tvarkymo, naudojimo, valdymo ir pan. modelị.

Šalyje daugybe atveju, kada parkai buvo privatizuojami dalimis, pavyzdžiui: Lančiūvos, Lentvario, Žagarès dvarų parkai ir pan. Todèl reikia imtis priemonių Žemès reformos įstatymo (str. 9, 13 ir kt.) pataisu dvaro sodybos su parku vientisumui įteisinti.

Šiandien didžiają dali - apie $70 \%$ - visu senujų dvaru parku dar valdo valstybe. Tiesioginiai jų valdytojai yra rajonų, miestelių savivaldybès, seniūnijos, regioninių parkų administracijos, mokslo, mokymo įstaigos ir pan. Nemalonu, bet, kaip tvirtina L. Januškevičius, tenka konstatuoti, kad dauguma šių parkų (apie 65 \%) yra gana apleisti ir valstybės saugomi kol kas tik teoriškai. Parko toli gražu nepakanka tik įtrauktį̣ Nekilnojamųjų kultūros vertybių registrą. Jị reikia ne tik saugoti, bet ir atkurti, tvarkyti. Pagal šiandieninę būklę gerai tvarkomi yra vos keliolika valstybès valdomų parkų, tai Palangos botanikos parkas, Biržų, Raudonès ir Vytėnu pilių parkai, Kretingos, Renavo, Rokiškio, Veisèjų, Baisiogalos, Burbiškio (Radviliškio raj.), Rietavo, Užutrakio, Verkių, Markučių ir kiti. Dèl to yra aktuali istorinio parko, sodo ir pan. savininko ar naudotojo, kuris nuolat ji prižiūrètų, tvarkybos ir tausojamojo naudojimo priemonėmis užtikrintų tvarumą, problema. Šiuo klausimu, straipsnio autoriaus manymu, ne- atidèliojant turètų būti priimtas Lietuvos vyriausybès nutarimas.

Šalies dvarų parkų esamos būklès tyrimų rezultatai verčia ieškoti priežasčių, kodèl susidarè tokia nepatenkinama padètis. Panagrinèkime kai kuriuos pagrindinius šalies įstatymus, ministerijų ísakymus ir įstatymo igyvendinamuosius teisès aktus, kurie daro įtaką istorinių sodų ir parkų apsaugai ir tvarkymui.

2007 m. birželio 28 d. priimtame Lietuvos Respublikos želdynu istatyme yra apibrěžtos istorinio želdyno, istorinio želdyno atkūrimo, želdynu apsaugos savokos, nustatyti bendrieji želdynu apsaugos ir tvarkymo principai: „želdynus ir želdinius būtina išsaugoti kaip estetiškai, ekologiškai, istoriškai ir kultūrai svarbius kraštovaizdžio elementus“, turi būti „išlaikomas istorinių želdynų ir juose arba greta jų esančių pastatų ansamblių ar kompleksų ir jų tarpusavio funkcijų vientisumas" ir pan. Tai seniai laukti ir labai reikalingi teiginiai, kurie, straipsnio autoriaus manymu, atliks svarbų vaidmenị saugant istorinius želdynus. Želdynų ìstatymo VII skyriuje „Kultūrinès paskirties želdynai ir valstybinès reikšmès parkai" yra nustatyti skyriaus pavadinime įvardintų želdynų apsaugos ir tvarkymo bendrieji reikalavimai. Tačiau, kaip buvo pažymèta LR Valstybinès kultūros paveldo komisijos $2010 \mathrm{~m}$. lapkričio 26 d. sprendime Nr. S-9 (163), ju igyvendinima nustatantys teisès aktai iki šiol neparengti.

2010 m. rugpjūčio 25 d. nutarimu Nr. 1239 Lietuvos Respublikos Vyriausybe patvirtino labai reikšmingus istorinius želdynus liečiančius dokumentus: „Valstybinès reikšmés parkų nuostatus" ir „Valstybinés reikšmès parku sarašą. Šiu dokumentu analizè leidžia teigti, kad ju kokybe kelia ir kai kuriu abejonių. Pagal "Nuostatus“ istoriniais parkais galima laikyti parkus, kurie atitinka tik du kriterijus: pirmasis - XVIII-XX a. ikurti arba rekonstruoti pagal E. Andre, L. Gucevičiaus, M. Knakfuso, G. F. Kuphaldto, K. Podčašinskio, A. Gaulios, R. ir A. Kiškių, T. Šešelgienès, A. Tauro, L. Čibiro parengtus projektus; antrasis - medžių ir krūmų (tarp jų introdukuotų) rūšių, porūšių, varietetų ar formų skaičius yra ne mažesnis kaip 20. Argi šie du „Nuostatuose“ išvardinti kriterijai atskleidžia visus istorinio parko atrinkimo kriterijus? Šio straipsnio autoriaus manymu, taip nèra. Istoriniu želdynu, tarp ju parkų, vertinimas turi büti tiesiogiai susijęs su laikotarpio kultūriniu tapatumu, su poreikiu išsaugoti ši istorini kultūros paveldo objektą. Istorinio parko atrankos vertinimo procesas turètu prasidèti nuo parko amžiaus cenzo ir autentiškumo požymiu patikros, nuo meniniu parko kraštovaizdžio savybiu ir ju vertingumo nustatymo, jo planinès erdvinès struktūros bei kompozicijos, istorinio meninio stiliaus pagrindiniu požymiu išryškinimo ir įvertinimo, želdynų ir ju asortimento, komponavimo 
principu atskleidimo bei įvertinimo, mažuju architektūros ir taikomosios dekoratyvinés dailés objektu įvertinimo ir t. t. Kaip matyti, tai sudetingas parko atrankos vertinimo procesas, kuris negali apsiriboti tik dviem vertinimo kriterijais. Lygiai taip pat abejoniu kelia ir LR Vyriausybès patvirtintas „Valstybinès reikšmès parkų sąrašas“, kuriame įrašyti tik 32 parkai. İ šį „,sąrašąa" nepateko tokie vertingi parkai kaip Biržų pilies, Abromiškių, Taujènų, Raguvèlès, Markučių, Plinkšių, Veisèjų, Jašiūnų ir kt.

Nežiūrint ị šiuos Vyriausybès nutarimo trūkumus, jis turi ir didele reikšmę. "Valstybinès reikšmès parku nuostatai " nustato ypatingą istorinę, architektūrinę, kultūrinę, mokslinę, estetinę, ekologinę ir dendrologinę vertę turinčių parkų valstybinèje žemèje ir ne tik jų atrankos kriterijus, bet ir jų apsaugą, tvarkymą, veiklą juose, jų lankymą ir kontrolę.

Siekiant skatinti šalyje istoriniu parku apsaugos, tvarkymo ir ju autentiškumo atkürimo procesa reikia inicijuoti LR Vyriausybès 2010-08-25 nutarimu Nr. 1239 patvirtintu „Valstybines reikšmés parku nuostatu“ tobulinima bei „Valstybinès reikšmès parku sąrašo" papildymą. Be to, šio straipsnio autoriaus manymu, reiketu parengti Lietuvos istorinių parkų ir sodų sąvadą, ị kuri būtina ịtraukti ne tik valstybinès reikšmès, bet ir kitu lygmenų (regioninius, vietinius) reikšmingiausius ir vertingiausius Lietuvos istorinius parkus bei sodus. Šiame sąvade būtų tikslinga pateikti istorinių parkų ir sodų apsaugos, fizinès ir meninès būklès ịvertinimą, nurodyti, kurie parkai pirmiausia tvarkytini ir pan. Tai padètu teisinèmis ir organizacinèmis priemonèmis tobulinti parkų bei sodu apsaugos atkūrimo ir finansavimo veiklos koordinavimą. Siekiant sèkmingai įvykdyti ši procesą būtina parengti ir patvirtinti istorinių želdynų vertingųjų savybių tyrimo bei jų apsaugos ir tvarkymo metodikas.

Nors pastaraisiais metais savivaldybiu bei ju imoniu lèšomis geriau vykdoma miestu bei gyvenviečiu želdynu ir želdiniu nuolatine priežiūra, tačiau esama daug trūkumu saugant, tvarkant ir atkuriant istorinius želdynus. Analizuojant pastaraisiais metais parengtu savivaldybių bendruosius planus tenka konstatuoti, kad juose stokojama būtent istorinių želdynų esamos būklès analizès ir jų apsaugos bei atkūrimo sprendinių. Todell, kaip tvirtina žinomas šalies paveldosaugininkas P. Gražulis: „savivaldybès tokiu būdu jau iš anksto suplanavo artimiausią dešimtmetị netvarkyti istorinių želdynų, nes Želdynų i̇statymo nustatyta, kad želdynų apsaugos ir tvarkymo finansavimas pirmiausia yra planuojamas vadovaujantis savivaldybès teritorijos ar jos dalių bendraisiais planais", o jose istorinių želdynų nèra (Gražulis 2010).
Istoriniams parkams ir sodams apsaugoti, tvarkyti ir atkurti reikalinga finansine parama. Tačiau valstybe nepakankamai skiria tikslinių lèšų istoriniams parkams, sodams bei dvarų sodybų ir pilių ansambliams kompleksiškai tvarkyti. Pritaikant dvarų sodybas turizmui istorinis parkas taip pat netampa prioritetu. Nèra privačių istorinių parkų ar sodų praktinès apsaugos sistemos: priežiūros, tvarkymo ir atkūrimo skatinimo svertų, apimančių ir finansavimą, neparengti praktiški priežiūros, kompleksinio tvarkymo bei finansinès paramos teisès aktai (LR VKPK sprendimas 2010). Todèl tam, kadšiu klausimų sprendimas pajudètu i prieki, LR Vyriausybe turi numatyti istoriniu parku ir sodu moksliniu tyrimu ir valstybinès reikšmés parku priežiüros bei tvarkymo darbu (atstatymo, pertvarkymo ir atnaujinimo) kasmetini finansavima.

Atlikta istorinių želdynų analizè liudija, kad sèkmingesniam finansinių išteklių iš LR vyriausybinių fondų bei Europos Sąjungos paramos lešųu ịsisavinimui reikia dabar žymiai geriau pasiruošti. Istoriniai šalies parkai ir sodai beveik neturi planavimo dokumentų bei konkrečių techninių projektų. Todèl vienas išsvarbiausiu uždaviniu - ịvairiu lygmenu istoriniu parku, sodu tvarkymo ir apsaugos specialiuju planu rengimo suintensyvinimas. Bütų tikslinga ịstatymiškai numatyti ivairiu lygmenų kraštovaizdžio tvarkymo specialiuosius planus integruoti i bendruju planu sistemą kaip privalomas bendrujų (generaliniu) planu dalis (Bezaras 2010).

Bütina parengti šalies istoriniu želdynu apsaugos ir nacionalinio lygmens kraštovaizdžio tvarkymo specialuji plana, kuris turètu būti apsvarstytas su profesine visuomene ir specialistais. Reikia pradèti rengti ir kraštovaizdžio architektūros ịstatymą.

Apibendrinant galima konstatuoti, kad istorinių želdynų tvarkymo ir apsaugos procese turètų būti žymiai aktyvesnis LR kultūros ministerijos vaidmuo, nes pagal $2004 \mathrm{~m}$. rugsèjo $28 \mathrm{~d}$. LR nekilnojamojo kultūros vertybių apsaugos ịstatymą Nr. IX-2452 „nekilnojamojo kultūros paveldo apsaugos valstybinị administravimą organizuoja ir už jị atsako kultūros ministras. Kultūros ministras iggalioja ministerijos padalinius ir prie ministerijos ịsteigtas institucijas atlikti apsaugos funkcijas. Valstybinių institucijų ir kūrybinių sąjungų (tarp jų Lietuvos kraštovaizdžio sąjungos ir pan.) bei visuomeninių organizaciju bendradarbiavimas rengiant teisès aktus ir planavimo dokumentus, istorinių želdynų apsaugos ir tvarkymo klausimais turètų būti aktyvesnis“.

Tačiau kol mes dar sprendžiame ir bandome pasiekti geresnių rezultatų istorinių želdynų tvarkymo procese, Pasaulis nužengè toliau. Jungtinių Tautų švietimo, mokslo ir kultūros organizacija (UNESCO) 
svarsto naują tarptautinị dokumentą „Rekomendacija dèl istorinio urbanistinio kraštovaizdžio išsaugojimo“, kuris turètų būti priimtas dar šiais metais UNESCO Generalinès konferencijos 36-toje sesijoje. Šiame dokumente istorinis miesto kraštovaizdis yra miesto teritorija, suprantama kaip istoriškai susiklosčiusios kultūrinès ir gamtinès vertybès, peržengiančios ,istorinio centro“ ar "ansamblio" sąvoką ir apimančios platesnị miesto kontekstą ir generalinę jo aplinką. Istorinio miesto kraštovaizdžio metodas paremtas prielaida, kad protingas didesnès miesto teritorijos planavimas prasideda būtent nuo didesnio masto istorinio miesto kraštovaizdžio raidos supratimo. Tai padès išsaugoti istorinio kraštovaizdžio tapatumą ir jo paveldo vertybes. Tad šalies visuomenès, valstybinių ir profesiniu institucijų laukia nauji iššūkiai, kuriems jau šiandien reikia ruoštis.

\section{Istorinių parkų atkūrimo proceso kai kurie aspektai}

Lietuvos Respublikos valstybinè kultūros paveldo komisija (LR VKPK) 2010 m. lapkričio $26 \mathrm{~d}$. apsvarstè esamą Lietuvos istorinių parkų ir sodų būklę ir konstatavo, kad „istoriniai želdynai dažniausiai nèra tinkamai prižiūrimi, nevykdomi fundamentiniai tyrimai ir atkūrimo, restauravimo darbai. Lietuvoje 1990-2010 metais neatkurtas nei vienas istorinis želdynas, tačiau esama restauruojamų atkuriant sunaikintas parkų dalis" (VKPK sprendimas 2010).

Šiandien istorinių sodų ir parkų atkūrimui, jų stiliaus autentiškumo ir jų savitumo išsaugojimui Europos Sąjungoje skiriamas didelis dèmesys. Šalis stengiasi atkurti bent po kelis skirtingo stiliaus parkus su būdingaisiais bruožais. Tai puikiai matyti apsilankius Vienoje, Amsterdame, Hamburge, Londone, Romoje, Rygoje, Bauskeje ir kitur.

Istorinių parkų atkūrimo praktikos ir specialiosios literatūros analizè rodo, kad šis atkūrimo veiksmas yra labai sudètingas ir reikalaujantis specialaus profesinio pasiruošimo. „Atkuriant istorinị sodą ar parką, svarbiausia išsaugoti ir atkurti šio objekto stiliaus autentiškumą, išryškinant būdingą šiam stiliui bruožų sankaupą: planinius erdvinius ir kompozicinius ypatumus, želdinių asortimentą ir komponavimo principus, mažosios architektūros objektų vieningą autentišką stilių, išlaikyti parko visumos vieningumą ir labai svarbu išsaugoti jo dvasingumą (genius loci)“"(Jakovlevas-Mateckis 2009). Žinomas šalies menotyrininkas V. Petrušonis siūlo vertinant parko kompleksą skirti ypač didelį dèmesį kultūriniam jo kontekstui (2010).

Autoriaus atlikta trumpa Lietuvos istoriniu sodu ir parkų meno stiliu raidos ir ju atkūrimo teisinés bazès būklès analizè leidžia teigti, kad atkūrimo procesas vyksta nepatenkinamai. Šalyje turime vos kelis teisingai atkurtus ar atkuriamus parkus, tai istorizmo stiliaus Palangos bei Užutrakio parkai ir modernizmo stiliaus Kauno Karo muziejaus sodas ir kt. Tačiau dauguma puikių mūsų šalies klasicizmo, romantizmo, istorizmo stiliaus parku dabar jau yra beveik praradę šiems stiliams būdingų bruožų visumą ir pavirto eiliniais želdynais.

Todèl, kai Vilniaus miesto savivaldybe 2005 m. užsibrěže tikslą atkurti Senamiesčio branduolyje esantị gerai išsilaikiusį istorinį moderno stiliaus Sereikiškiu parka, kraštovaizdžio architektu visuomenè ir vilniečiai tam entuziastingai pritaré. $2006 \mathrm{~m}$. buvo parengti projektiniai parko atkūrimo koncepcijos pasiūlymai (archit. G. Miknevičienè). Šie pasiūlymai buvo apsvarstyti, gerai ịvertinti ir patvirtinti visose miesto savivaldybès institucijose. Vèliau $2007 \mathrm{~m}$. techninio projekto užduočiai parengti SI „Vilniaus planas“ sudarè specialistų komisiją, i kurią buvo pakviestas ir šio straipsnio autorius. Specialistų komisija kartu su projekto autoriais parengè užduotị, suformulavo projekto tikslą - atkurti pirmąji viešąjį ir vieną iš vertingiausių Lietuvoje moderno stiliaus parkų - Sereikiškių parką Vilniuje (autorius dail. A. Strauss, parkas ikurtas $1886-1888 \mathrm{~m}$.) - ir numate pagrindinius projektinius uždavinius. Tai turèjo būti ramaus poilsio parkas. Paskui jau naujas autorių kolektyvas (proj. vadovè arch. J. Večerskytė-Šimeliūnè) pradejo rengti techninị parko projektą.

2009 m. techninis projektas buvo baigtas. Naujo projekto sprendiniai kraštovaizdžio architektūros specialistus tiesiog apstulbino. Projekto autoriai nepagristai perkvalifikavo parko istorinį meninį stiliu, vietoj moderno stiliaus ìvardydami jị istorizmo stiliumi, turinčiu baroko bruožų. Tai didelè neprofesionalumo klaida, nes Strausso iggyvendintame projekte nèra istorizmui būdingų kelių praeities stilių ar interpretavimo samplaikos (eklektikos), o juo labiau baroko bruožų. Projekte neleistinai interpretuojamas A. Strausso parko suplanavimas, keičiama pagrindinè parko ašies kryptis, aikštès forma, panaikinama trumpoji „dengta“ aleja (covered alley), kuri dažnai būdavo įrengiama moderno stiliaus parkuose ir pan. Projekte pateikti mažieji kraštovaizdžio architektūros statiniai ir ịrenginiai tarpusavyje nèra stilistiškai susieti, nesudaro visumos, nieko bendro neturi su moderno stiliumi.

Tačiau didžiausia Sereikiškiu parko atkūrimo projekto klaida yra pagrindiniu šio istorinio parko funkciju keitimas. Pagal Strausso ideją, o ir pagal 2006-2007 m. patvirtintus projektinius pasiūlymus bei techninio projekto rengimo užduotị tai turèjo būti ramaus poilsio parkas. Tačiau jau pradètas igyvendinti techninis projektas numato radikaliai pakeisti jo paskirtị ir istorinị 
parką paversti daugiafunkciu. Vèl siūloma, kaip buvo sovietiniais metais, užgriozdinti ji aikštelèmis, ịrenginiais ir statiniais. Ydingos „kultūros ir poilsio“ parko idejos buvo atsisakyta jau pirmaisiais nepriklausomybès metais, bet šiandien vèl primygtinai siūloma pastatyti oranžeriją - restoraną su atvira aikštele, arbatinę - kavinę prie įejimo ị parką, šachmatų aikštelès statini su ledaine-kavine, dvi vaikų žaidimo aikšteles, didelę paaugliu žaidimo (riedučiu ir riedlenčių) aikštelę, karuselę, petankès žaidimo aikštelę, muzikos paviljoną, žaidimų pievą, Vilnios pakrantèje prie pasivaikščiojimo tako nutiesti dar ir $2,5 \mathrm{~m}$ pločio, $550 \mathrm{~m}$ ilgio dviračių taką ir pan. Čia pramogaus ir ilsèsis didelis skaičius lankytojų, nes aplinkui nėra tokio pobūdžio parkų. Sereikiškių parko plotas yra labai mažas, tik 9 ha (palyginkime - Vingio parkas užima apie 260 ha). Pagal metodines parkų projektavimo rekomendacijas tokie daugiafunkciai parkai projektuojami ne mažesniame kaip 50-60 ha plote. Todèl tokioje mažoje parko teritorijoje sutalpinti tiek daug statinių, įrenginių, aikštelių ir pan. yra ne tik neracionalu, bet ir parkui pražǔtinga.

Tačiau svarbiausia, kad projekto autoriai (SI „Vilniaus planas“) nesiskaite ir su Sereikiškių parko, kaip istorinio želdyno, statusu ir pažeidè LR kultūros paminklo UIP Vilniaus senamiesčio apsaugos reglamento reikalavimus. Visi šie ir kiti Sereikiškių parko restauravimo ir atkūrimo neigiami aspektai buvo autoriaus išsakyti kelis kartus Vilniaus miesto savivaldybès vadovams, miesto merams J. Imbrasui ir V. Navickui, LR aplinkos ir kultūros ministerijų atsakingiems vadovams ir pan.

Apie pavojų Sereikiškių parkui skelbẻ Lietuvos kraštovaizdžio architektų sąjunga, buvo rašomos peticijos, šių eilučiu autorius rašè straipsnius ị mokslo ir profesinius žurnalus, bet visi liko neišgirsti (JakovlevasMateckis 2008, 2009, 2010).

$2010 \mathrm{~m}$. pavasarị prasidejo Sereikiškiu parko dra$m a$, skubos tvarka parke buvo iškirsta trumpoji alejja, medžių grupès, griuvo sveikutèliai medžiai: liepos, klevai, uosiai ir pan. Parke iškirsta daugiau kaip 200 medžių. Buvo ruošiami laisvi plotai naujiems parko statiniams ir irenginiams. Parko restauravimo ir atkūrimo bendra kaina buvo didelè, net $18 \mathrm{mln}$. Lt (Europos Sąjungos struktūrinių fondų - $14 \mathrm{mln}$. Lt, Vilniaus savivaldybès - $2 \mathrm{mln}$. Lt, rèmèjų - $2 \mathrm{mln}$. Lt). Tačiau išaiškejjus, kad Europos Sąjunga lèšų šiam tikslui dar nèra skyrusi, darbai sustojo, rèmèjų neliko. Todèl šiandien kyla klausimas, kam ir kodèl reikejo šitaip skubèti? (4 pav.).

$2010 \mathrm{~m}$. vasarą atrodè, kad kova už jo išlikima jau pralaimèta, tačiau išaiškejo, kad kraštovaizdžio architektų, gamtos mylètojų ir miesto bendruomenès

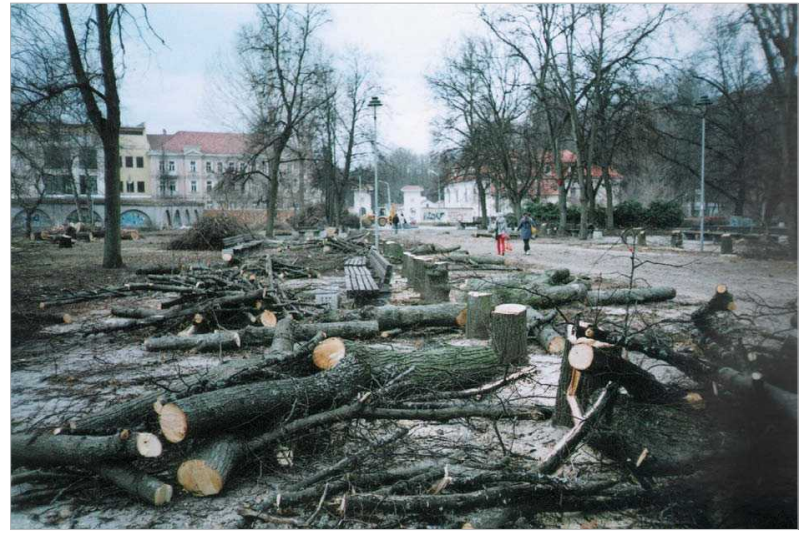

4 pav. 2010 m. pavasarị prasidèjusios Vilniaus Sereikiškių moderno stiliaus parko naikinimo dramos epizodas. Ruošiamos naujos erdvės pramogu aikštelèms, atrakcionams ir pan.

Fig. 4. An episode of the destruction drama of the modernstyle Sereikiškių park in Vilnius, which commenced in spring of 2010. New spaces are prepared for entertainment, amusement and other sites

pastangos išsaugoti Sereikiškių parką nenuejjo veltui. 2010 m. rugpjūčio 25 d. Lietuvos Respublikos Vyriausybe prièmè nutarima Nr. 1239 „Dèl valstybinès reikšmès parku nuostatu ir valstybinès reikšmès parku sąašo patvirtinimo". I šị valstybines reikšmes parku sąrašą, kurị sudaro 32 parkai, įrašytas ir Vilniaus Sereikiškiu parkas.

LR Vyriausybès patvirtintuose „Valstybinès reikšmés parkų nuostatuose“ aiškiai nurodyta, kad „parkuose skatinama veikla, puoselejjanti, išryškinanti ir propaguojanti istorines, architektūrines, kultūrines, mokslines, estetines, ekologines, dendrologines vertes, nepažeidžiant Parko būklès gali būti vykdomi moksliniai tyrimai, mokymas, atskirų gamtos ir kultūros objektų Parke stebėsena, švietèjiška ir kultūrinè veikla (koncertai, parodos) ir pažintinè rekreacija."

Nuostatuose akcentuojama, kad valstybinès reikšmès ,parkuose draudžiama: keisti ir žaloti Parkų kompoziciją, jų erdvinę-planinę struktūrą (reljefą, vandens telkinius, takų tinklą), mažinti istorinę, architektūrinę, kultūrinę, estetinę, ekologinę vertę, naikinti ar žaloti parko želdinius, mažuosius kraštovaizdžio architektūros ir inžinerinius statinius, gamtos ir kultūros paveldo objektus“.

Nuostatuose pažymèta, kad valstybinès reikšmès parkų apsaugą ir tvarkymą organizuoja parkų valdytojai. Sereikiškių parko valdytoja yra Vilniaus miesto savivaldybè, kuri patvirtino techninị parko projektą ir išdavè statybos leidimą barbariškam šio parko naikinimui. Dabartiniu metu, susidarius tokiai situacijai, naujoji Vilniaus miesto savivaldybés vadovybe turi imtis skubiu priemoniu savo pirmtakų klaidoms ištaisyti. Reikia koreguoti technini projekta ir atkurti pirmaji vie- 
šaji moderno stiliaus, valstybinès reikšmès Sereikiškiu parka, vadovaujantis LR Vyriausybés patvirtintomis valstybinés reikšmés parku nuostatomis.

Autoriaus nuomone, Vilniui reikalingas pramogų ir poilsio parkas, tačiau ne istorinio, valstybinès reikšmès Sereikiškių parko vietoje. Tinkamiausia tokio pobūdžio vieta Antakalnio gale, prie Neries kairiojo kranto esančiame miške (Lizdeikos g.).

Atsižvelgiant i tai, kad Lietuvoje šiuo metu yra 32 valstybinés reikšmés parkai, kuriu būklè daugeliu atvejų, kaip nurodo LR valstybinè Kultūros paveldo komisija ir kaip matyti iš autoriaus pastebejjimų, yra ne per geriausia, šio straipsnio autoriaus nuomone, $L R$ kultūros ir aplinkos ministerijos turètu sudaryti parku fizines ir menines büklès ivvertinimo, saugojimo ir tvarkymo perspektyvinius bei kasmetinius planus.

Valstybinès reikšmès parkai yra reikšminga šalies kultūros vertybè, todèl savivaldybės, kurių teritorijose yra parkų, turètų periodiškai (ne rečiau kaip kartą per metus) spaudoje, interneto svetainèse informuoti visuomenę apie parkų būklę ir atliekamus bei numatomus atlikti tvarkymo darbus. Toks administracijos, specialistų ir visuomenès bendradarbiavimas, straipsnio autoriaus nuomone, duotų gerų rezultatų.

Istoriniu sodų, parku atkūrimo procesas, kuris galetu tapti mums geras pavyzdys, sèkmingai vykdomas kaimynineje Latvijoje. Netoli Lietuvos sienos prie Bauskès miestelio vykdomi didžiuliai restauravimo darbai atkuriant baroko stiliaus Rundalès rūmus ir parka. Rundalès ansamblis jau XVIII a. buvo vadinamas „Baltijos Versaliu“. Rūmų ir parko ansamblis buvo Kuršo kunigaikščio, Rusijos imperatorès Anos Joanovnos favorito Johanno von Bühreno rezidencija. Parko ir rūmų projekto (1735-1736 m.) autorius, Rusijos imperatoriaus rūmų architektas Francesco Bartolomeo Rastrelli. Parkas ir rūmai buvo statomi vienu kartu 1736-1740 m. Parkas susideda iš trijų dalių: reprezentacinio sodo-parterio, parko ir medžioklès miško parko. Parko plotas apie 10 ha, jo suplanavimas geometrinis, simetriškas. Šị parką dažnai vadindavo "prancūziškuoju parku." Prieš rūmus ịrengta paradinẻ aikštè su įvažiavimu ir arklidèmis. Už rūmų, parko puseje, ịrengtas reprezentacinis sodas su kiliminiu parteriu, trimis fontanais ir rožynais. Už jų tęsiasi parkas, kurio planinę erdvinę struktūrą formuoja penkių spindulinių alèjų vẻduoklinè kompozicija, primenanti Versalio parką. Šios alèjos kerta ne tik parką, bet ir už jo esantị medžioklès mišką, kurio plotas dabartiniu metu siekia 32 ha, ankstesnis buvo žymiai didesnis. Parko alèjos tarpusavyje sujungtos skersiniais takais. Alejų ir takų pakraščiai buvo apsodinti karpomomis gyvatvoremis ir gyvasienėmis, kurios sudarè uždarus sodelius, vadinamus bosketais. Bosketuose buvo įrengtas žaliasis amfiteatras, labirintas, arbatos paviljonas, iškylos pievelè ir pan. Rūmai su reprezentaciniu soduparteriu ir parkas apjuosti vandens kanalu (5, 6 pav.).

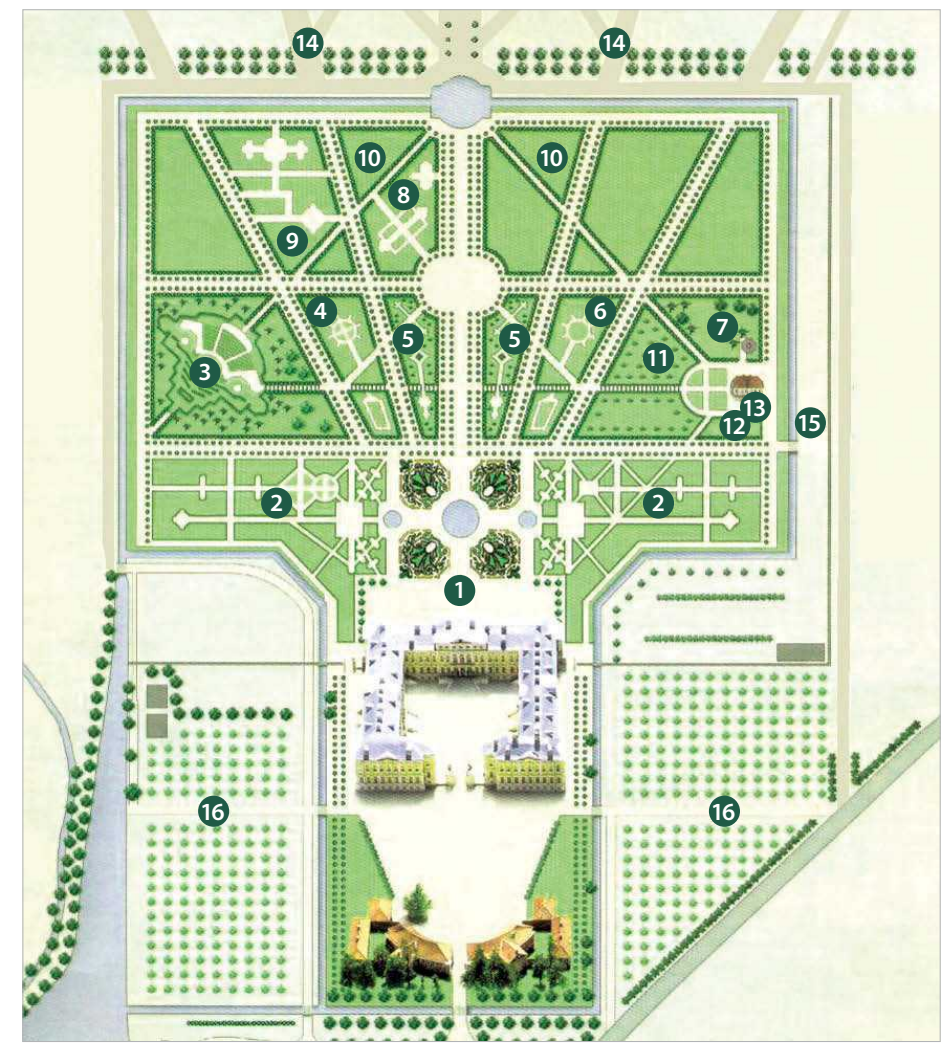

5 pav. Rundalès rūmų baroko stiliaus parko plano schema (autorius archit. F. B. Rastrelli, 1735-1736 m., parko atkūrimo projektas Sankt Peterburgo "Giproteatr" 1975-1978 m.): 1 - rūmai ir reprezentacinio sodo ornamentinis parteris; 2 - rožynas; 3 - žaliasis amfiteatras; 4 - Olandijos bosketas; 5 - alyvu sodas; 6 - mèlynasis bosketas; 7 - iškylos pieva su paviljonu; 8 - paviljonas „Po auksine vaza“; 9 - memorialinis bosketas; 10 - žydinčių medžių bosketas; 11 - dekoratyvinių vaismedžių sodas; 12 - bijūnų kolekcija; 13 - sodininko namas; 14 - medžioklès miškas; 15 - vandens kanalas; 16 - vaismedžių sodas

Fig. 5. The blueprint of the baroque-style park at Rundāle Palace (author architect F. B. Rastreli, 1735-1736, the reconstruction plan by Giproteatr, Sankt Petersburg, 1975-1978): 1 - the Palace and the ornamental parterre of the representative garden; 2 - rose garden; 3 - the green amphitheatre; 4 - the Dutch bosket; 5 - olive-tree garden; 6 - the Blue Bosket; 7 - the Picnic Meadow with a pavilion; 8 - the pavilion Under the Golden Vase; 9 - the memorial bosket; 10 - the bosket of blooming trees; 11 - the garden of decorative fruit-trees; 12 - collection of peonies; 13 - a gardener's house; 14 - the hunting forest; 15 - water cannel; 16 - the fruit-tree garden 

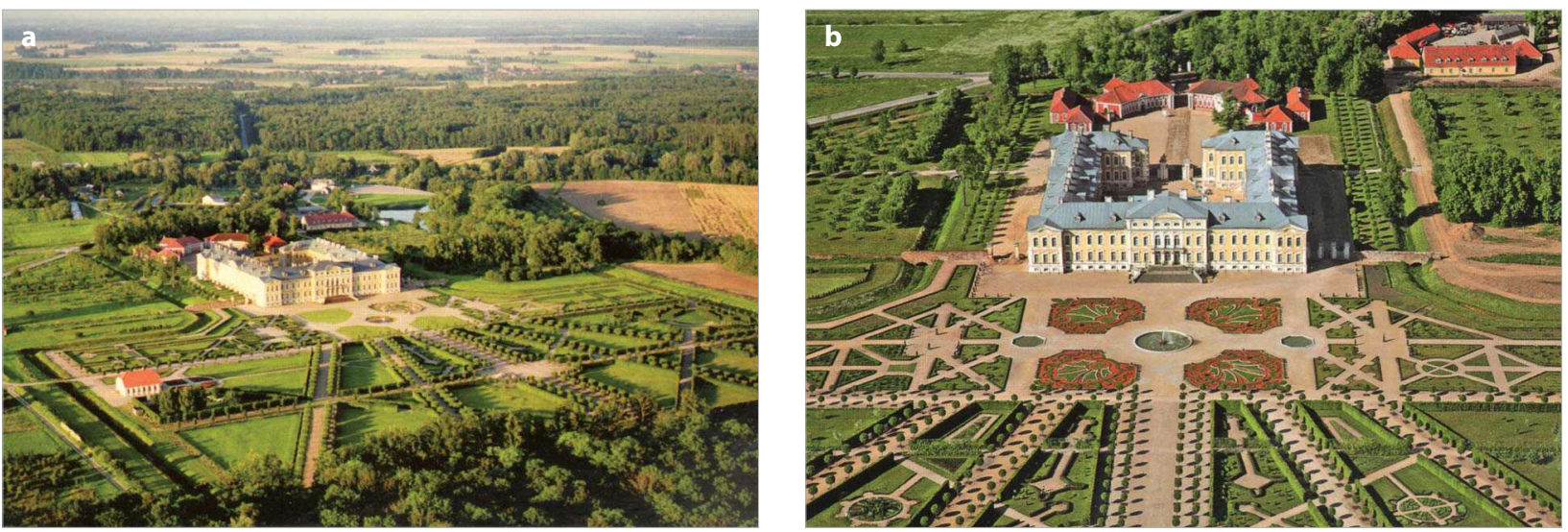

6 pav. Atkurto barokinio Rundalès rūmų parko vaizdai (nuotr. V. Leijere, I. Lancmanis): a - bendras parko vaizdas; b - rūmų parko reprezentacinis sodas-parteris

Fig. 6. Images of the restored baroque-style park at Rundāle Palace (photos by V. Leijere, I. Lancmanis): a - the general view of the park; $b$ - parterre of the representative garden of the Palace

Vanduo ị kanalą buvo paduodamas iš užtvenkto upelio tvenkinio. Kanalas buvo reikalingas geresnei parko augalų vegetacijai užtikrinti ir jiems prižiūrèti. Pagal rezidencijos sodininko Chistopher Weyland ataskaitas, rengtas 1736-1739 m. laikotarpiu, sužinome, kad parke buvo pasodinta: 328185 liepos, 5005 kaštonai ir 1885 ąžuolai. Reprezentaciniame rūmų sode-parteryje buvo įrengti ornamentiniai gèlynai ir rožynai, kuriuose augo prancūziškos, Damasko, ịvairiaspalvès rožès ir pan. Prie parko buvo įrengti keli vaismedžiu sodai, kuriuose buvo pasodinta obelų, persikų, slyvu ir vyšnių medžių.

Parko kūrimo darbe dalyvavo keli tūkstančiai darbininkų. Yra žinoma, pavyzdžiui, kad 1736-1737 m. čia dirbo daug kareivių, jų skaičius svyravo nuo $670 \mathrm{iki}$ 3819,1738 m. dirbo 745 valstiečiai ir dar 1155 valstiečiai kasè kanalą. İdomu pažymèti, kad ir rūmų bei parko ansamblio autorius architektas F. B. Rastrelli, formuojant parką, dažnai atvykdavo iš Sankt Peterburgo ir gyvendavo darbininkų stovykloje.

XIX a. laikotarpiu parkas, nežiūrint karų, šeimininkų kaitos, išsaugojo pagrindinius barokinio parko bruožus. Tik valdant grafui Valerijonui Zubovui XIX a. pradžioje buvo atlikti nežymūs keitimai - parterio šone vietoj gèlyno pasodintos eglès ir piramidinès tuopos, o grafo Petro Šuvalovo nurodymu $1860 \mathrm{~m}$. šalia rūmų buvo prisodinta kaštonų. Bet tai buvo nežymios parko korektūros. Po Pirmojo pasaulinio karo ir Žemès reformos, įvykdytos Latvijoje 1920 m., parkas neteko turtingų valdytojų ir toliau jau buvo beveik neprižiūrimas. Nekarpomos medžių alèjos, gyvasienès gyvatvorès pavirto miško medžiais ir krūmais. Tik $1972 \mathrm{~m}$. ịsteigus Rundalès rūmų muziejų ir pradejus rūmų restauravimą kilo idejja atkurti barokinị parką. Šiam tikslui igyven- dinti 1974 m. Latvijos mokslų akademijos Botanikos instituto specialistai atliko parko želdinių esamos būklès analizę. Analizès rezultatai parodè, kad senieji parko medžiai sunykę, blogos būklès, parkas priaugęs savaiminių medžių ir krūmų. Todèl siekiant atkurti pirminę parko išvaizdą, buvo rekomenduota juos pašalinti ir sodinti naujus medžius ir krūmus, kurių asortimentas būtų toks pats kaip XVIII a. čia augusių augalų asortimentas. 1975-1976 m. Leningrado (dab. Sankt Peterburgo) projektavimo institutas "Giproteatr" parengè barokinio parko atkūrimo projektą. $1975 \mathrm{~m}$. parke ir rūmų reprezentaciniame sode buvo pradèti kirsti medžiai, krūmai, raunami jų kelmai. Šis morališkai sunkus, bet būtinai reikalingas darbas, norint atkurti XVIII a. barokinị parką, buvo baigtas $1978 \mathrm{~m}$. Paskui karpomos parko alejjos, bosketai, pergolès, gyvatvorès ir pan. nuosekliai buvo užsodinamos medžiais, krūmais, buvo įrengiamos alejų ir takų dangos ir pan. Medžių bei krūmų asortimentas parko atkūrimo laikotarpiu tam tikrais atvejais buvo iš dalies koreguojamas, siekiant panaudoti ilgaamžiškesnius, atsparesnius šalčiams, mechaniniam karpymui ir ligoms augalus, kurie geriausiai gali perteikti baroko laikotarpio augalų karpymo (topiarų) meno charakteri. Taip, pavyzdžiui, parke veisiamoms gyvasienèms vietoj anksčiau čia auginamų liepų (Tilia cordata Mill.) pradèti sodinti paprastieji skroblai (Carpinus betulus L.). Paprastieji skroblai plačiai naudojami šiandien ir Vakarų Europos barokiniuose parkuose. Tačiau, kiek tai buvo galima atkuriamame parke siekiama sodinti XVIII a. populiarius augalus, o kad parko lankytojai geriau orientuotųsi, kurios augalų rūšys yra senosios, o kurios naujosios, parke augalai ženklinami, nurodant augalo pavadinimą, datą ir kilmę. Taip parko admini- 
stracija atlieka ir vieną iš savo funkcijų - šviesti lankytojus ir skatinti juos domètis kraštovaizdžio architektūros klausimais, kurie nèra plačiai žinomi visuomenei (Lancmane 2009).

Rundalès parko atkūrimo darbai suaktyvèjo atkūrus Latvijos nepriklausomybę. Buvo atkurtas prieš rūmus buvęs reprezentacinis sodas-parteris, rožynai, užbaigti formuoti parke bosketai, pergolès, tvarkomas už parko esantis medžioklès miško parkas. Kadangi parke neišliko kadaise jị puošusių mažųjų statinių bei mažosios architektūros objektų ir nepavyko atrasti jų brèžinių, jie buvo atkurti pagal Europos barokiniuose parkuose esančius analogus. Atkuriant Rundalès parką ne viskas iš karto pavyko, tačiau nuosekliai taisomos klaidos ir tobulinamas barokinis parko įvaizdis (Lancmane 2009) (7 pav.).

Parkui atkurti ir išlaikyti valstybė kasmet skiria finansavimą. Finansinę paramą skiria ir šalies verslo įmonès. Pavyzdžiui, rožynų įrengimą finansavo
„Latvijas Mobilais Telefons“ iłmonė. Būtų tikslinga, kad ir mūsų verslo įmonès pasektų kaimynų pavyzdžiu ir finansiškai paremtų istorinių parkų restauravimą ir atkūrimą.

Rundalès rūmu parko atkūrimo patirtis, teigiami ir neigiami proceso aspektai galetu itin pasitarnauti atkuriant Vilniuje Sapiegu rezidencijos baroko stiliaus parka bei Valdovu rūmu renesansinį sodą. Šie atkurti istoriniai želdynai kartu su rūmais sudarytu stilistine vienovę ir dar geriau atskleistu aukštą mūsų šalies sostinés senosios kultūros vertybių lygi.

\section{Išvados}

1. Lietuvoje turime visų istorinių laikotarpių kraštovaizdžio architektūros stilių parkų, kurie yra neįkainojama šalies kultūros paveldo vertybè. Todèl visuomenès ir valstybès pagrindinis tikslas yra išsaugoti šį kultūrinị palikimą, jo istorinį ir kultūrinị reikšmingumą ir atkuriant išlaikyti šio kultūrinio
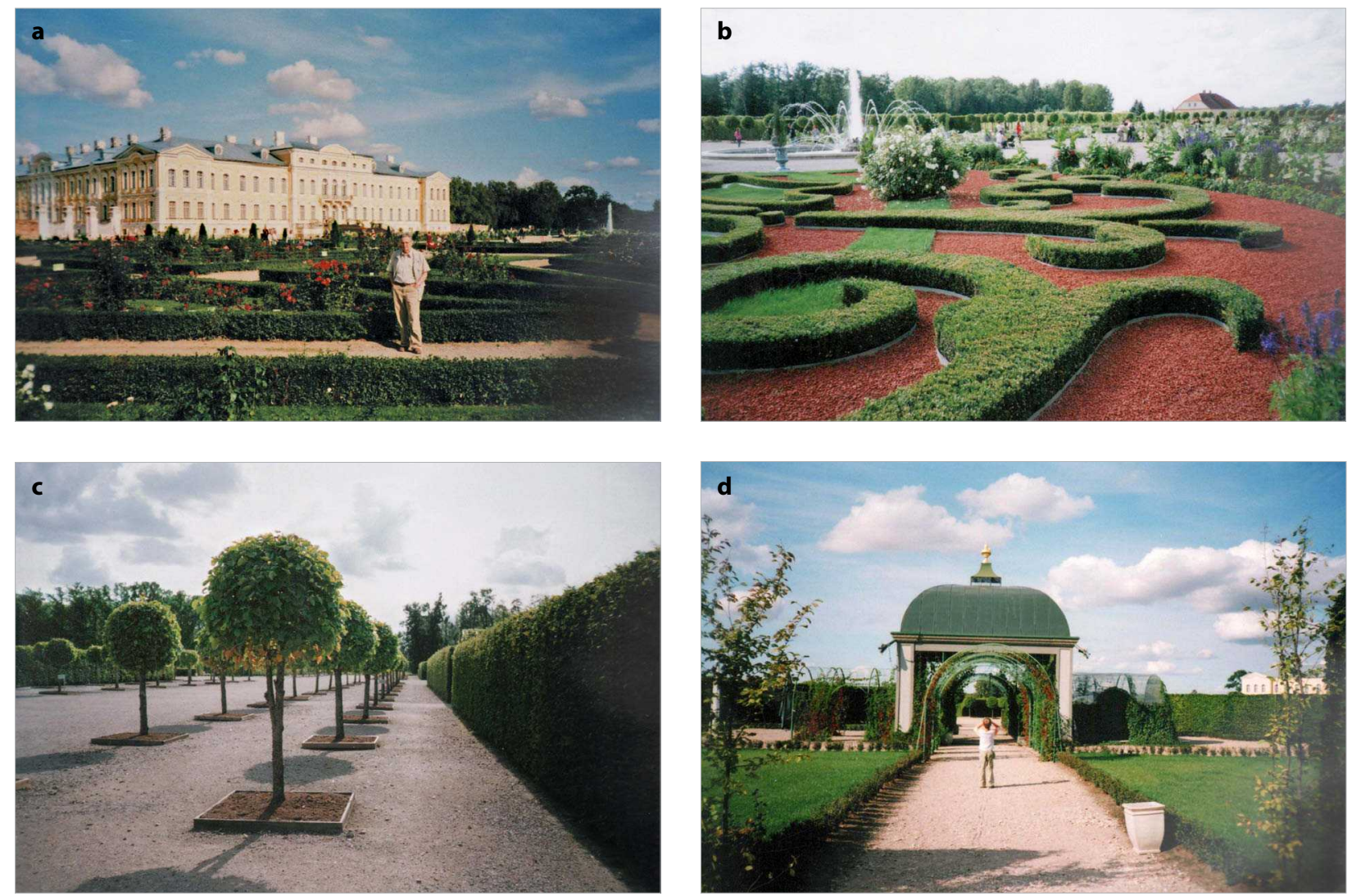

7 pav. Rundalès rūmų barokinio parko fragmentai (autoriaus nuotr.): a - rūmų parko reprezentacinio sodo-parterio fragmentas; b - ornamentinis karpytų gyvatvorių parteris; c - pagrindinè parko alejja, apsodinta karpomomis liepomis, ir aukšta bosketo gyvasiené; $\mathrm{d}$ - paviljonas ir pergolè tako sankirtoje, apsodinti amūriniu vynmedžiu

Fig. 7. Fragments of the baroque-style park at Rundāle Palace (photos by the author): a - a fragment of the parterre of the representative garden of the Palace; $b$ - the ornamental parterre of trimmed hedges; $c$ - the main avenue of the park lined with trimmed linden trees and high living wall of the bosket; $d$ - a pavilion with a pergola in the cross-section of the path, both planted with the Amur grape 
palikimo meninio stiliaus tapatumą, autentiškumą, būdingų bruožų sankaupą ir konkretaus istorinio laikotarpio dvasią (genus loci).

2. Siekiant išjudinti šalyje istorinių parkų apsaugos, tvarkymo ir jų autentiškumo atkūrimo procesą reikia prašyti LR kultūros ministerijos parengti Lietuvos istorinių parkų bei sodų sąvadą, i kurị būtina įtraukti visų lygmenu (valstybinès, regioninès ir vietinès reikšmès) reikšmingiausius ir vertingiausius šalies istorinius parkus ir sodus. Siekiant sèkmingai ịvykdyti ši procesą, būtina parengti ir patvirtinti istorinių parkų bei sodų fizinès ir meninès būklès įvertinimo, apsaugos ir tvarkymo metodiką.

3. Prašyti LR kultūros ministerijos parengti istorinių parkų ir sodų mokslinių tyrimų darbų ir valstybinès reikšmès parkų priežiūros, tvarkymo bei projektavimo darbu (atstatymo, pertvarkymo ir atnaujinimo) perspektyvinius ir metinius planus ir siekti, kad LR vyriausybè nustatytų kasmetinį šių darbų finansavimą. Būtina siekti, kad iki $2020 \mathrm{~m}$. Lietuvoje būtų atkurta bent po vieną kiekvieno istorinio meninio stiliaus (renesanso, baroko, klasicizmo, romantizmo, istorizmo ir moderno) parką ar po kelis tokius parkus.

4. Atsižvelgiant ị tai, kad Vilniaus Sereikiškių parkas $2010 \mathrm{~m}$. rugpjūčio $25 \mathrm{~d}$. LR Vyriausybès nutarimu Nr. 1239 ịtrauktas ị Valstybinès reikšmès parku sąrašą, prašyti LR kultūros ministerijos, kad itpareigotų Vilniaus miesto savivaldybę, kaip parko valdytoją, nutraukti parke vykdomus darbus, nes dabartinio parko techninio projekto sprendiniu tikslai ir uždaviniai neatitinka naujai patvirtintu „Valstybinès reikšmès parko nuostatų", ir pakoreguoti technini projektą.

5. Prašyti LR aplinkos ministerijos:

- Saugomų teritorijų ir Teritorijų planavimo įstatymų naujai rengiamose redakcijose įtraukti skyrių apie istorinių želdynų esamos būklès analizę, apsaugos ir tvarkymo sprendinius;

- numatyti istorinių želdynų specialiuosius planus integruoti į bendrųjų planų sistemą kaip privalomas bendrųjų (generalinių) planų dalis;

- paspartinti želdynų ỉstatymo VII skyriaus „Kultūrinès paskirties želdynai ir valstybinės reikšmès parkai“ pavadinime ịvardintų želdynų apsaugos ir tvarkymo bendrųjų reikalavimų igyvendinimą nustatančių teisès aktų parengimą.

\section{Literatūra}

Adomonis, J. 1994. Nuo taško iki sintezès. Vilnius: VDA l-kla. 175 p.

Bezaras, V. 2010. Kraštovaizdžio apsaugos ir formavimo politika: teisinè aplinka ir strateginès kryptys, Kraštovaizdžio architektūra - patirtis, tendencijos, perspektyvos: Kraštovaizdžio architektūros forumo 2010 mokslo darbai. Sudarytojai ir atsakingieji redaktoriai Konstantinas Jakovlevas-Mateckis ir Vaiva Deveikienè. Vilnius: LKAS. $178 \mathrm{p}$.

Florencijos chartija 1982. ICOMOS Tarptautinè istorinių želdynų chartija.

Jakovlevas-Mateckis, K. 2009. Miesto kraštovaizdžio architektūra. I tomas. Miesto kraštovaizdžio architektūros raida ir teorijos pagrindai: monografija. Vilnius: Technika. 412 p.

Jakovlevas-Mateckis, K. 2008. Moderno stiliaus kraštovaizdžio architektūra Lietuvoje ir Vilniaus Sereikiškių parko atkūrimo problema, Urbanistika ir architektūra [Town Planning and Architecture] 32(1): 5-16.

Jakovlevas-Mateckis, K. 2010. Vilniaus Sereikiškių parkas: išlikimo drama, Kultūros barai (9): 19-29.

Januškevičius, L. 2004. Lietuvos parkai. Kaunas: Latutè. 488 p.

Januškevičius, L. 2010. Po gražiausius Lietuvos dvaru parkus. Kaunas: Latutè. 324 p.

Lancmane, L. 2008. The 21st Century Interpretation of Francesco Bartolomeo Rastrelli's Design of the Park. Renovation Problems and Solutions. Bauska: Rundales pils muzejs.

Lietuvos Respublikos „Nekilnojamujų kultūros vertybiu apsaugos" istatymas. $2004 \mathrm{~m}$. rugséjo $28 \mathrm{~d}$. Nr. IX - 2452, Vilnius.

Lietuvos Respublikos Vyriausybès nutarimas „Dèl valstybinès reikšmès parku nuostatu ir valstybinès reikšmés parku sarašo patvirtinimo“. 2010 m. rugpjūčio 25 d. Nr. 1239, Vilnius.

Lietuvos Respublikos želdynu ịstatymas, Valstybės žinios. 2007. Nr. 80-3215.

Lukšionytè-Tolvaišienè, N. 2008. Architektūrologijos pagrindai. Kaunas: VDU. 104 p.

Mačiulis, A. 1997. Architektūra. Stiliai, kompozicija, menu squeika. Vilnius: VDA leid.

Markejevaitè, L. 2002. Konteksto reikšmè meninès formos tektonikai architektūroje, Urbanistika ir architektūra [Town Planning and Architecture] 26(1): 49-57.

Mocevičius, A. 2010. Lietuvos sodu ir parku meno raida ir tendencijos XVII-XX a.: daktaro disertacija. Vilnius: Technika.

Pasaulio paveldo vietoves - Vilniaus istorinio centro (senamies čio) būkle bei autentiškumas. Pažyma VKPK $20091218 \mathrm{~d}$. posédžiui. Pažymą parengė J. Markevičienè, A. Gražulis ir kt. (Rankraštis).

Petrušonis, V. 2010. Kultūrinio konteksto reikšmè vertinant architektūrinị kompleksą, Urbanistika ir architektūra [Town Planning and Architecture] 34(5) (specialus numeris): 252-261.

Valstybinès kultūros paveldo komisijos sprendimas „Dèl istoriniu želdynu tvarkymo ir apsaugos Lietuvoje“. $2005 \mathrm{~m}$. rugsejo $30 \mathrm{~d}$. Nr. S-6-(114). Vilnius.

Valstybinès kultūros paveldo komisijos sprendimas „Dèl Lietuvos istoriniu parku ir sodu apsaugos". 2010 m. lapkričio $26 d$. Nr. S-9(163). Vilnius. 


\section{ANALYSIS OF LITHUANIAN HISTORIC PARKS EVOLUTION AND SOME ASPECTS OF THE RENEWAL PROBLEMS}

\section{K. Jakovlevas-Mateckis}

Abstract. The process of protection, regulation and restoration of historic parks is influenced by many factors. Therefore, the paper briefly analyses the evolution of art style of historic garden-parks of Lithuania, the state of legal instruments for their protection, as well as positive and negative experience in relation to regulation and restoration of historic parks positive. Some suggestions for improvement or renewal of country's historic parks are offered.

Keywords: historic parks, parks of state importance, art style of parks, renewal of parks, legal base of parks renewal.

\section{KONSTANTINAS JAKOVLEVAS-MATECKIS}

Dr Habil, Prof. Dept of Urban Engineering; Dept of Fundamentals and Theory of Architecture, Vilnius Gediminas Technical University (VGTU), Sauletekio al. 11, 10223 Vilnius, Lithuania. E-mail: km@vgtu.lt

Doctor Habil of the Humanities (architecture), 1983. Doctor, 1969. Employment: Visiting Professor (Rome University "La Sapienza" Bialystok Polytechnic University (Poland), Kaunas University of Technology); senior research worker, Lithuanian Design Institute. Membership: member of International Information Academy, academician. Publications: author and co-author of over 160 research papers, 9 monographs and 20 books. Projects: author of over 98 projects of architectural and environmental design. Research interests: industrial architecture, formation of urban and industrial landscape, environmental design. 